\title{
LEGISLATIVE INTERVENTION IN THE CONFLICT BETWEEN ORTHODOX AND DIRECT-SELLING DISTRIBUTION CHANNELS
}

\author{
Joseph SidNey Gould*
}

Darwin's truism that in nature nothing is constant except change is applicable to most phases of human activity and social relationships. It is particularly true of the field of merchandising or distribution. Despite this, there is an aspect of human nature which tends to retard change-a native conservatism. Old customs, methods, become crystallized in tradition. Once established, each agent in the field of distribution, regardless of type, persists in claiming to be the "regular" or "orthodox" channel. All newcomers are regarded as mere interlopers. So it is that today distribution through the wholesaler, jobber, and established retail merchant has become institutionalized into the orthodox scheme of merchandising; and channels for the distribution of goods and services which defy this pattern are viewed as unorthodox, a threat to the established mode of doing business. Just as self-preservation is a law of individuals, so is it a principle of vested institutions. Today's conventional pattern of distribution has not let the challenge of its supremacy go unheeded. It has sounded the cry of battle in the market place; but, increasingly uncertain of victory there, it has sought to entrench itself behind the wall of legislation. Peddler, chain store, transient merchant, vending machine, mail order house, department store, market cooperative-all have become involved in the legislative decision to play favorites in the economic struggle thus precipitated. A part of the story of this legislative intervention is told here.

\section{Mobile Merchants}

The house-to-house salesmen employed by manufacturing and distributing concerns as well as independent itinerant vendors, peddlers, and transient merchants may be distinguished from the so-called orthodox distributors by their mobility, since they move from locality to locality without regard to municipal and state boundaries. It is a commentary on the present-day classification of this group as interlopers that they have played such a prominent part in the history of merchandising. In the Middle Ages, the regular type of trader was either an artisan who traveled from place to place with goods he himself manufactured, or the peddler who purchased

*A.B., 1921, M.A., 1922, Clark University; Ph.D., 1929, Brookings Graduate School for Economics and Government. Head of the Department of Economics and Business Administration; Director of the Bureau of Economics and Business Research, University of Delaware. Contributor to periodieals. 
stocks of goods in a town or at a fair and carried them about in a pack for sale. Since much of the commerce of Europe in the thirteenth, fourteenth, and fifteenth centuries was transacted at fairs, the itinerant merchant or peddler served an important need because it was impossible for everyone to visit the fairs or market towns for the purchase of goods. The peddler who purchased the goods at these markets or fairs carried them through the countryside selling to the people in their homes or bartering for goods which could be disposed of to advantage.

This same valuable economic function was performed by the hawker, peddler, and itinerant merchant in our early American life. The rôle of the Yankee peddler in the development of America is interestingly depicted in Hawkers and Walkers in Early America. ${ }^{1}$ During much of the early history of our country, peddling was an active form of retail distribution, many New England and Pennsylvania factories owing their early start to sales made by such peddlers. ${ }^{2}$ These traders and peddlers, actually the forerunners of our domestic commerce, were of various types. There were the general peddlers who hawked useful "Yankee" notions-pins, needles, hooks and eyes, scissors, razors, combs, buttons, spoons, small hardware, books, shawls, cotton goods, lace, and perfume. Then there were the specializing itinerant merchants such as the tin peddlers of essences, dyes, woodenware, pottery, books, and similar items. However, even these specialists frequently carried several sidelines of goods, vending such cumbersome articles as sewing machines, spinning wheels, cabinet organs, and agricultural machinery. Peddlers were further classified as "trunk peddlers," that is, dealers in small wares, essences, and such, who carried their goods in one or two small oblong tin trunks slung on their backs by a web harness or a leather strap, and peddlers who loaded large wagons with dry goods, hats, boots, shoes, clocks, firearms, hardware, and even furniture. The latter merchants travelled greater distances.

The early peddlers were comparatively young men who were adventurous and "able to cope with the dangers of the wilderness through which they had to travel."3 With the passage of years, as the roads became safer and the wilderness was cleared, peddling slipped into the hands of older men. Both the young and the old peddlers played an important rôle in the widening of our frontiers. The first commercial move westward was made by Indian traders - by traders and peddlers who carried goods from New York and Pennsylvania into the territory lying beyond the fringe of the settlements. The Dutch of New York were trading regularly with the Iroquois at Albany by $\mathbf{I} 700$ and the Pennsylvanians crossed the Alleghanies with their pack trains and penetrated to the Ohio and the Wabash in the early part of the eighteenth century. Although in general the reputation of the early Yankee trader was not very savory, as is well indicated by the observation of visitors to our country even as late as 1833 , it must be remembered that many prominent men in

\footnotetext{
I Wright, Hawkers and Walkers in Early America (1927).

2 Converse and Huegy, Elements of Marketing (1940) 49.

- WRJGH, op. cit. supra note $\mathrm{I}$, at 24 .
} 
our American life started their careers as peddlers. This list includes such names as Collis P. Huntington, Parson Weems, and Benedict Arnold.

The status of the peddler and itinerant merchant today can be seen from the following table, which indicates the relative importance of house-to-house selling in the distributive field. It is to be noted that during the depression period the peddler, canvasser, and others engaged in direct-selling activities increased in number, and declined when economic conditions improved. The increasing facilities of trans-

TABLe I

Concerns Engaged in House-to-House Selling ${ }^{4}$

\begin{tabular}{|c|c|c|c|c|c|c|c|}
\hline \multicolumn{3}{|c|}{ ESTABLISHMENTS } & \multicolumn{2}{|c|}{ SALES } & \multicolumn{3}{|c|}{ EMPLOYEES } \\
\hline Year & Number & $\begin{array}{c}\text { Percent } \\
\text { of Total } \\
\text { Retail } \\
\text { Establishments }\end{array}$ & $\begin{array}{c}\text { Total in } \\
\text { Thousands of } \\
\text { Dollars }\end{array}$ & $\begin{array}{c}\text { Percent } \\
\text { of Total } \\
\text { Retail } \\
\text { Sales }\end{array}$ & $\begin{array}{l}\text { Per Estab- } \\
\text { lishment }\end{array}$ & $\begin{array}{c}\text { Percent } \\
\text { of Total } \\
\text { of all Retail } \\
\text { Establishments }\end{array}$ & $\begin{array}{l}\text { Expenses } \\
\text { as Percent } \\
s \text { of Sales }\end{array}$ \\
\hline 1929 & $\ldots \ldots$ I66I & $0 . x$ & $93,96 \mathrm{I}$ & 0.2 & 18.6 & 0.7 & 45.0 \\
\hline 1933 & $\ldots \ldots 7026$ & 0.5 & I87,368 & 0.4 & $5.2^{*}$ & r.3 & 40.9 \\
\hline I935 & $\ldots \ldots \sigma_{349}$ & 0.4 & $I 25,316$ & 0.4 & $5 \cdot 3$ & 0.8 & $4^{1.5}$ \\
\hline
\end{tabular}

* Full time only.

portation have given these mobile merchants such a competitive status as to arouse the merchants who operate established stores. In fact this competition is deemed to be so keen that in many municipalities and states ordinances and laws have been passed ostensibly designed to prevent unfairness in competition, to equalize the burden of taxation, and to prevent fraud on consumers. However, in many instances the intent was farther reaching, and litigation ensued. In a number of cases the courts have held these laws and ordinances to be unconstitutional, either because the regulation was too severe, the tax too large, competition too completely stifled, or the burden an unreasonable one on interstate commerce. In point is the unanimous decision of the United States Supreme Court, on December 23, I940, which invalidated a North Carolina law imposing a $\$ 25^{\circ}$ privilege tax on transient merchants or out-of-state retailers displaying wares in sample rooms of hotels. ${ }^{5}$

The power of states to regulate, license, and tax mobile merchants is generally recognized as well established, although the power actually to prohibit them from engaging in business is highly questionable, except perhaps as to the prohibition which may be imposed on the peddling of goods considered to be injurious to public health, morals, or welfare. The manner of imposition of license fees on peddlers varies among the several states. Some impose a tax upon the occupation, while others adhere to any one or a combination of the following classifications: (r) according to article sold, (2) according to the method of transportation, or (3) according to the population of the sales area. Thus in Alabama ${ }^{b}$ a state fee of

4Alexander, Marketzing (1940) r80. $\quad{ }^{5}$ Best \& Co., Inc. v. Maxwell, 3 II U. S. 454 (1940).

${ }^{8}$ Ala. Acts 1935, No. 194, \$348, schedules r04, 146; Acts Ex. Sess. 1936, No. 43; Acts 1936-1937, No. 230; Acts 1939, No. 18. 
$\$ 250$ and a county fee of $\$ 125$ are imposed on a peddler of drugs, ointments, and medical preparations professed to treat or cure disease, injury, or deformity, not including patent medicines sold in original packages. These fees are not modified by the mode of transportation used in selling the listed items. However, in the vending of patent and proprietary medicines and household remedies in original packages, such as toilet articles, spices, extracts, flavoring, soaps, insecticides, stock and poultry supplies, the tax varies as follows:

(a) When using a motor vehicle for transportation, $\$ 40$ state and $\$ 40$ county.

(b) When using other than a motor vehicle for transportation, \$20 state and \$10 county.

(c) When travelling without a vehicle, \$ro state and \$ro county.

In addition to the above there is a general tax on all vendors and itinerant merchants of $\$ 15$ state and $\$ 5$ county when using a vehicle other than a motor car.

A departure from the above bases is to be found in the new type of regulatory law passed by the state of Nebraska in $1937 .^{7}$ Under it the license fee is imposed not upon the privilege of doing business as an itinerant merchant but rather as a payment for the use of the state's highways to transport the goods to be sold. It is claimed that the law was occasioned by the marked increase in the use of the highways by itinerant truckers. Five other states, California, Iowa, Montana, Wisconsin, and Wyoming, enacted laws in 1939 which were closely patterned after that of Nebraska. ${ }^{8}$ The license fee varies considerably among these six states. In Nebraska an itinerant merchant must pay an annual license fee of $\$ 25$ and an additional occupation tax of $\$ 25$ on each vehicle he uses in his business. In California and Wyoming the fee is $\$$ Io, while Montana requires an annual license fee of $\$$ roo, and Wisconsin \$200. Iowa imposes a fee based on the maximum weight of the load to be carried where the vehicles are not registered in the state. The schedule is as follows: load not to exceed rooo lbs., \$1o; load not to exceed $3000 \mathrm{lbs}$., $\$ 25$; load in excess of $3000 \mathrm{lbs}$., $\$ 40$. If the vehicle is registered in the state, the fee is $\$ 2$ regardless of the weight of the load. All six of the states require the posting of a surety bond ranging in amount from $\$ 25^{\circ}$ in California to \$Iooo in Montana. Wisconsin requires two bonds, one of $\$ 500$ to guarantee the payment of all taxes, penalties, and interest, and another amounting to \$1000 to protect the public from fraud.

In order to strengthen the hand of the several states in passing legislation designed to regulate the activities of peddlers and itinerant merchants operating interstate, bills were introduced in the 76 th Congress of the United States. Illustrative is H. R. 8796, providing that "no individual engaged in selling or in soliciting orders for goods, wares, or merchandise, or other commodities shall be relieved, by reason

${ }^{7}$ Neb. Laws 1939, p. 669 .

${ }^{8}$ Laws and Ordinances Regulating Transient Dealers and Closing Out Sales (Am. Retail Fed., 1939) 13. A comparable development has taken place in the municipal area, with some litigation resulting. Sec McIntire and Rhyne, Municipal Legislative Barriers to a Free Market, infra this issue. 
of his relation to interstate commerce, from the operation of the laws of any State, or political subdivision thereof, requiring licenses or bonds of, or otherwise regulating the activities of, individuals so engaged."

A 1939 analysis made of the principal state statutory provisions concerning peddlers ${ }^{10}$ reveals that while all the states to a greater or lesser extent regulate this activity in a restrictive manner, many make specific exemptions which are distinctly promotive in their incidence. In Indiana and Kansas residents are exempted; in New York licenses are required only of those selling foreign-made goods. Twenty states exempt persons selling dairy, poultry, or farm products produced by themselves; New Mexico and Wisconsin do so where the peddler is a resident of the state. Thirteen grant this exemption of agricultural products to all peddlers whether or not they were themselves the producers; twenty-one name other types of articles the peddling of which is exempted from licensing requirements; while seven apply the principle of self-production broadly to include all types of manufactured goods.

Similar analysis of transient merchant laws ${ }^{11}$ reveals like tendencies. Of the twenty-eight states requiring the licensing of transient merchants, as variously defined, about half provide one or more kinds of exemptions identical with those granted in the case of peddlers. Thus four states specifically exempt persons selling farm and garden products raised by themselves, New Mexico again limiting the favor to residents. Four more jurisdictions extend the grant to goods manufactured as well as produced by the one selling; while another three specify that transient sale of agricultural products, whether or not raised by the seller, is exempt, with four others applying this principle to perishable farm products sold at any established municipal market.

It would thus appear that in some of the states the regulatory provisions aim to do more than "protect" or "equalize competitive advantages" between fixed and more permanent as against the mobile and more transitory channels of distribution. By means of exemptions the statutes decidedly discriminate between agricultural and other commodities. It is not the type of merchant that is exempted but the merchant who sells a type of commodity. This is especially true in the case of those states which exempt persons selling agricultural products whether or not raised by the seller. ${ }^{12}$

\section{MaIL-Order Houses}

The ordering of goods by mail is a practice as old as the mails; the establishment of a retail business dependent solely upon mail orders is comparatively modern. The

\footnotetext{
'H. R. 8796, 76th Cong., 2d Sess. (r940). Compare H. R. 9045 of the same session providing that "no individual, association, or corporation engaged in selling or in soliciting orders for goods, wares, or merchandise or other commodities as itinerant vendors, transient merchants, and mail-order merchants shall be relieved by reason of his relation to interstate commerce, from the operation of the laws of any State or political subdivision thereof in which he may operate and where no discrimination is made against such individual, assaciation, or corporation domiciled within this State providing for taxation, licensing, regulation, or supervision of such activitics of individuals, associations, or corporations." 10 Supra note 8, at 14.

${ }^{12}$ Diverse forms of product favoritism by government are discussed in Note on Governmental Product Favoritism, supra this issue.
} 
history of the mail-order business is essentially that of the two leading firms, Montgomery Ward, Inc., founded in 1873 , and Sears, Roebuck \& Co., established in 1893, and of Chicago, whose geographical position made her the logical home for the major companies in the business. A. Montgomery Ward and his brother-in-law George R. Thorne considered the original aim of their business "to serve as a supply house for the farmers' granges."13 Among the objectives of the grange movement was the encouragement of cooperative buying. When this feature of the movement did not prove successful, they decided to enter the mail-order business.

Sears, Roebuck \& Co. owes its origin to an interesting venture on the part of Mr. Richard Sears when he was a station agent in New Redwood, Minnesota. When Mr. Sears notified a mail-order watch company that the customer to whom a watch was to be delivered C.O.D. could not be found, they replied urging him not to return the watch but to sell it to someone else. He did so and netted a profit of \$2. This experience prompted him to order other watches which he sold at a similar profit. It was not long before he left the employ of the railway concern and started a watch and jewelry mail-order business of his own in Minneapolis. This business he moved to Chicago and after a few years disposed of it profitably. It was not long, however, before he and A. C. Roebuck, a watch repair man, started another mail-order house in Minneapolis under the name of Sears and Roebuck. Within five years the concern showed remarkable growth and again the strategic location of Chicago was a factor in deciding to move the business to that city.

There were two dominating reasons for the growth of the mail-order businesssale of goods not readily available in small communities, and prices lower than those of local retailers. It is in these communities that marked competition between mailorder concerns and regular stores has occurred most noticeably. The mail-order houses apparently forced local retailers to reduce their prices. ${ }^{14}$ To realize the keenness of the competition it is necessary to recall the intense hostility of rural and small-town merchants towards the mail-order houses.

The appearance of any new form of distribution has always caused established retailers to fear the complete abolition of the independent merchant. It is so in the present conflict with the chain stores. It was so with the coming of the department stores and the mail-order houses. Today, of course, the department store is an accepted, established American institution. But there was a time, beginning with John Wanamaker's "Grand Depot" in Philadelphia, opened in 1876 , when the department store loomed as the great threat to the existence of small enterprise. No effort was spared by local merchants to turn the ill will of the public towards these newer enterprises. Attempts were made to regulate them by discriminatory legislation. ${ }^{15}$ For example, in Pennsylvania "a bill was introduced providing for a total of $\$ 100,000$ in license fees to be collected from the department stores of the

\footnotetext{
${ }^{13}$ Nrstrom, The Economics of Retalling (rgig) 288.

14 Converse and HuegY, op. cit. supra note 2, at 348 .

${ }^{15}$ Nichols, The Chain Storx Telis Its Story (I940) 127.
} 
Commonwealth. A year later, the State of Missouri passed a law taxing the department stores $\$ 500$ on each and every classification of goods sold."16

Agitation against the mail-order houses followed the same pattern. Montgomery Ward and Sears, Roebuck \& Co. became the targets for many "lecturers" particularly in the Southern and Middle Western states. In some states political aspirants made issues of the mail-order houses and urged legislation to curb their growth. In many towns "high bon-fires in the public square destroyed mail-order catalogues in order, local merchants said, to keep 'freedom of opportunity' alive in America."17 More recently, manifestations of hostility have appeared in the form of "sticker" ordinances, the purpose of which is to discourage the mail-order selling of plumbing supplies, and in the barrier features of state use taxes. ${ }^{18}$ Local building codes, drafted in the era before pre-fabrication of dwellings and calling for construction standards differing from those properly used in pre-fabrication, are also being employed to strike at the direct selling of this new product through both general variety and single commodity mail-order houses. ${ }^{19}$

Nevertheless, direct-by-mail selling has progressed despite such attempts to hamper its growth until today it has attained a rather respectable, accepted status. In I935 there were 378 establishments in the United States with nearly 41,000 employees, making a volume of catalogue sales amourting to $420,000,000$ dollars. It is estimated that between two-thirds and three-fourths of this volume of business was done by the two largest concerns in the field. ${ }^{20}$

Although mail-order houses are principal distributors to farmers, the larger concerns no longer consider the rural areas their major field for sales. An accurate break-down of the sources of revenue of the three leading companies is not available. However, it is believed that the proportions of urban and rural sales are close to the national division of approximately 65 percent urban and 35 percent rural. With the exception of Sears, Roebuck \& Co., so-called urban sales come primarily from the small-sized communities. The recovery of sales by the mail-order house from the low levels of the depression years is indicated in Table II. It is significant that while the percentage of total retail sales for all distributive agencies for the year I939 was only 84 percent of the year 1929, the mail-order houses reached a record of 90 percent of 1929 in the year 1939.

\footnotetext{
${ }^{10}$ Id. at 127. The Missouri type legislation, constituting an early form of limitation on integration in the distributive field, is discussed in Cook, Legislative Restrictions on Marketing Integration, supra this. issue.

${ }^{17}$ Nichols, op. cit. supra note 15, at 128. See also CoHn, The Good Old Days (1940) 510 et seq.

${ }^{18}$ "The "sticker" ordinances are referred to by McIntire and Rhyne, Municipal Legislative Barriers to a Free Market, infra this issue; on the use tax, see Carlson, Interstate Barrier Aspects of the Use Tax, supra this issuc. See also note 22 , infra.

${ }^{10}$ See McIntire and Rhyne, Municipal Legislative Barriers to a Free Market, infra this issue. Maynard, Weidler and Beckman, Principles of Marketing, (3d ed. 1939) 130 el seq., list four types of mail-order retailing. Concerns representing three of these types now offer pre-fabricated houses.

${ }^{20}$ Alexander, op. cit. supra note 4 , at 204 .
} 
TABLE II ${ }^{21}$

Volume of Mail-Order Sales (Catalogue Only) ig29-I939

\begin{tabular}{|c|c|}
\hline Year & $\begin{array}{l}\text { Volume of Sales } \\
\text { (in millions of dollars) }\end{array}$ \\
\hline$x 929$ & 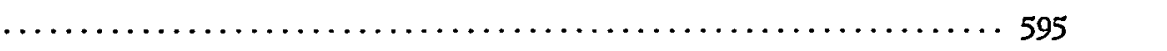 \\
\hline I930 & 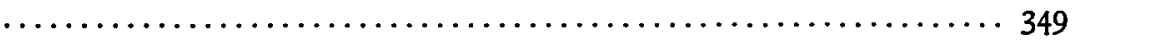 \\
\hline x93 & 259 \\
\hline 1932 & 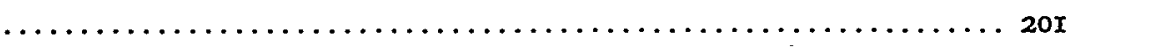 \\
\hline I933 & 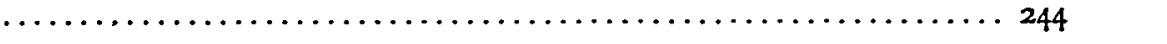 \\
\hline I934 & 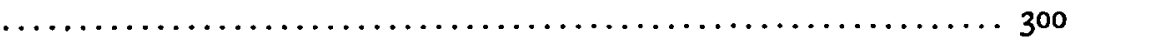 \\
\hline x935 & 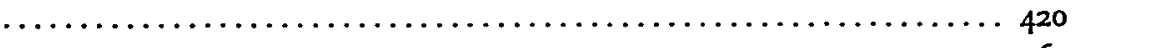 \\
\hline I936 & 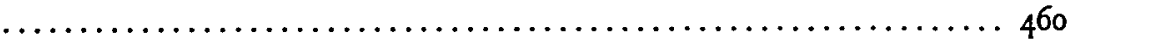 \\
\hline I937 & 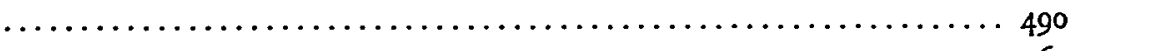 \\
\hline $193^{8}$ & " \\
\hline & 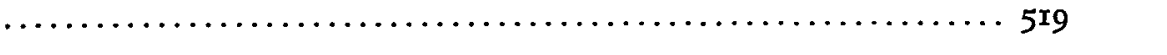 \\
\hline
\end{tabular}

In 1925, Sears, Roebuck \& Co., and in I926 Montgomery Ward, entered the urban communities by the establishment of a chain of retail stores in many cities from coast to coast. This put them in the retail field as large national chain-store companies and therefore subject to all the restrictive and regulatory legislation directed against chain stores. ${ }^{22}$ A second recent development in the mail-order field is the rise of the cooperative mail-order houses, of which there are now two outstanding companies. ${ }^{23}$ Thus are combined two direct-selling distribution channels.

\section{Vending Machines}

While at one time or another during the past forty years vending machines have been used for the retailing of a wide variety of products, the remarkable growth of this novel method of distribution took place during the past few years. There are no census figures available on sales made by vending machines. In I933, however, it was estimated that there were 6,000 operators, the three largest of which controlled nearly 200,000 machines. ${ }^{24}$ These figures do not include gambling devices, scales, games, lockers, and other machines vending a service only. Data compiled by associations in the vending machine business indicate that the industry multiplied itself tenfold during the period 1928 to 1939 . The estimated value of coin-operated equipment sold annually approximates $\$ 75,000,000 .{ }^{25}$ The production of coin-operated machines used for commodity vending has had a noticeable

${ }^{21}$ Industry Surveys (Dec. 6, 1940) 48 Standard Statistics No. 20, \$2, p. RT-1 4 ; and Retail Chains and Mail-Order Houses, Census of Business I935 (U. S. Dept. Com., 1937) 27.

${ }^{32}$ This particular form of legislative intervention in the struggle between competing distribution channels is detailed by Feldman, Legislative Opposition to Chain Stores and Its Minimization, infra this issue. By recent legislation in Minnesota, mail-order establishments in that state under the same management, ownership or control are taxed many times heavier than are other chains. See Minn. Laws Sp. Sess. 1937, c. 93, now MiNN. Stat. (Mason, Supp. I940) $\$ \$ 5887-18 \mathrm{a}-58887-18 \mathrm{t}$.

${ }^{35}$ For details, consult Burley, The Consumers' Cooperative as a Distributrve Agency (1939).

"Converse AND HuEgy, op. cit. supra note 2, at 332, quoting from Geo. B. Keck, Vending Machine Merchandising (Thesis for Master's Degree, University of Illinois, 1933).

${ }^{25}$ Schlicht, The Coin Machine Business (Aug. 1939) Aurowatic AGE. 
growth. Census statistics show a rise from 102,700 in 1933 to 475,415 in 1937. The principal use of vending machines at the present time is for the sale of five specific products-gum, nuts, candy, cigarettes, and soft drinks. However, the full diversity of commodities distributed through coin-operated machines includes music, ice, wood, stamps, stationery, soap, towels, razor blades, handkerchiefs, collars, collar buttons, even perfume. There is almost no end to this list.

In I935, cigarettes valued at $\$ 30,000,000$ were sold from automatic vending machines. This tremendous volume is impressive when compared to the mere $\$ 200,000$ gross when the cigarette vendors were first introduced only four years earlier. Chewing gum sales from machines at one cent a stick netted a total revenue of more than $\$ 5,000,000$ in 1935 . A single operator of peanut vendors reported sales of from 15 to 20 tons a month at the rate of half an ounce a penny. Another operator sold more than $1,000,000$ pounds of pistachio nuts in small driblets in less than a year. During five months of 1934 twelve carloads of a certain candy bar were sold through 150 vending machines located at the Century of Progress grounds. In the subways of New York the vending machines are said to have annual gross receipts of approximately $\$ \mathrm{r}, 000,000$. There are some 7,000 such machines on Chicago's elevated railroad platforms. ${ }^{26}$ The vending machines are located in thousands of railway and bus stations, and in other public places. They are to be found in America's industries among the lathes and presses of automobile factories, steel mills, packing plants, large retail stores, mail-order houses, and a variety of service establishments from restaurants to gasoline filling stations.

The phenomenal growth of this new distributive channel has already brought forth adverse criticism and even a number of attacks. ${ }^{27}$ To what extent this adverse reaction has imbedded itself in legislation is, however, difficult to gauge. Prohibitory legislation forbidding in three states distribution by vending machines of drugs, medicines, or poisons, ${ }^{28}$ and in one municipality sale of gasoline through automatic pumps, ${ }^{29}$ cannot definitely be said to be the product of competitive pressure rather than of genuine considerations for public safety. The same is true of the taxing and licensing legislation now to be found on the statute books of at least seventeen states; ${ }^{30}$ the evidence on the point is certainly meager. The operators insist that

\footnotetext{
${ }^{26}$ Slawson, Selling by Machinery (July 1937) 25 NAtion's Bus. 69. Some data on the magnitude of machine candy bar sales can be found in Hershey Chocolate Corp. et aux., 28 F. T. C. 1057 (1939).

${ }^{27}$ See Schlicht, supra note 25.

${ }^{28}$ Pa. Stat. Ann. (Purdon, Supp. 1940) tit. 18, \$4659; Cal. Business and Professtonat Code \$4010; Kan. Gen. Stat. ANn. (Corrick, I935) \$65-650.

${ }^{20}$ The Red Cloud, Nebraska ordinance was sustained against attack in Hawkins v. City of Red Cloud, I23 Neb. 487,243 N. W. 432 (I932).

${ }^{30}$ Ala. Acts 1939, No. 398, amending Ala. Gen. Acts 1935, No. 194, \$348, sch. 135, 154; 2 Ark. Dic. Stat. (Pope, I937) §13420, amended Ark. Laws 1939, act 201; Del. Laws 1939, c. 67 \$1; FLA. Comp. Gen. Laws (Supp. 1940) \$1279 (19); Ga. Laws 1935, pp. 42-43; 6 LA. Gen. Stat. (Dart, I939) $\$ 8607$ (mechanical musical instruments only); Miss. Laws I940, c. 122; MD. CodE ANN. (Flack, 1939) art. 56, \$23 (music boxes only); NEB. Comp. Stat. (1929) \$4I-104 (sandwich and lunch machincs only); N. C. CODE ANN. (Michic, 1939) \$788a (6x); Okla. Laws I939, c. 66, art. I8, \$4(d) (cigarctte vending machines only); S. C. Acts 1939, Act 346, §Ior, (I) (a); S. D. Code ANn. (I939) \$\$57.4101, 57.4102; Tenn. Code AN. (Williams, Supp. 1938) $\$ \$ 1248.72$ (a), 1248.73 (c); Tex. Stat. (Vernon,
} 
merchandising through the vending machine is a supplementary rather than a competitive channel of distribution. To a certain extent this is true, especially when the machine is located at a place where were it not for it no purchase would be made at all. However, it is not unreasonable to question the implication that all purchases from the "thousands" of vending machines always represent untapped "new demand" that would otherwise go unsatisfied. Thus the American Federation of Musicians claims the displacement of professional musicians where coin-operated "juke boxes" have been placed in the larger cafes and dance halls. This organization at least does not view as protective the taxes on these music machines that range from $\$ 5$ to $\$$ roo annually.

A stiff tax may not, however, be indicative of a purposeful intent to checkmate this new mode of distribution; the picture is confused by the fact that the slot machine has a reputation for both money-making and bad morals, either of which may explain high rates of tax. It would seem clear, for instance, that New York's authorization of municipal taxation of possession and operation of vending machines as a method of providing subsidies to housing authorities, ${ }^{31}$ is prompted by the apparent taxable capacity of the merchandise vending machine. On the other hand, state authorization of taxation by local subdivisions coupled with heavy taxes by the state itself must by its very cumulative weight have restrictive effect. Thus under North Carolina law $^{32}$ music machines can be and are taxed $\$ 20$ per year, soft drink machines $\$ 60$, although the localities are limited to $5^{\circ}$ percent of the state rate. $^{33}$ While some states carry a limited authorization to local subdivisions ${ }^{34}$ or none at all, Virginia sets no limit. ${ }^{35}$ The secretary of one of the vending machine trade associations considers a unit tax of even one dollar per year to be prohibitive for most types of merchandise vending machines. By this test much of the legislation must be deemed restrictive in its effect if not in its purpose. But if this seemingly low threshold is upped ten times the rates of some of the states would still meet the test of restrictiveness, and current proposals in the ig4I legislative sessions appear to run in the direction of exactions so heavy as to imply a definite purpose to effect competitive discrimination. ${ }^{36}$

1936) art. 7047a-I, amended Tex. Laws 3 d Sess. I936, c. 495, art. III, §4; VA. TAX CodE $\$ \S 590$, I98; W. VA. CODE ANN. (1937) §9I6, amended W. Va. Laws x939, c. II9I, \$1o.

${ }^{32}$ N. Y. Consol. Lsws, c. $44 \mathrm{~A}$, \$rio. The tax is not to exceed 50 cents per month. Excepted are machines placed in buildings owned or leased by federal, state, or city government or public authority.

${ }^{32}$ N. C. CODE ANN. (Michie, r939) $\$ 7880$ (6r).

${ }^{83}$ See also Miss. Laws 1940 , c. 122, where the state schedule, with a 50 percent municipal exaction additional, is as follows: ( 1 ) weighing machines $\$ 5$; (2) postage stamp machine $\$ 2$; (3) pictures, music or stencils: less than 5 cents, $\$ 4 ; 5$ cents to ro cents, $\$ 10 ;$ ro cents to 20 cents, $\$ 20 ;$ over 20 cents, $\$ 30$; (4) games: up to 5 cents, $\$ 8 ; 5$ cents to to cents, $\$ 20$; to cents to 20 cents, $\$ 40$; over 20 cents, $\$ 60$; (5) merchandise: up to 5 cents, $\$ 2.50 ; 5$ cents to xo cents, $\$ 10$; xo cents to 20 cents, \$20; over 20 cents, $\$ 30$; and (6) cigarettes (where privilege tax on selling cigarettes has been paid), $\$ 2$.

st of the seventeen states imposing fees or taxes, three, including North Carolina, authorize additional local exaction. Ala. Acts 1939, No. 398; Miss. Laws 1940, c. 122; N. C. Code (Michie, 1930) $\$ 7880(6 \mathrm{r})$.

SE VA. TAX CODE §rg8.

${ }^{38}$ E.g. Cal. A. B. 966 , imposing a $\$ 25$ annual tax on each cigar and cigarette vending machine; Ind. H. B. 316 , imposing on all vending machines rates of from $\$ 3$ for 1 cent machines to twice the sum 
Many of the states provide for a variety of exemptions from the license or tax. The following provisions are found in the Alabama law: ${ }^{37}$ ( 1 ) machines vending necessary articles on a non-profit basis to employees are exempt; (2) exemption is also granted where a person, firm, or corporation operating the place of business, or owning the machine, has a privilege license to sell the articles vended by machine. In case of vending to employees on private property (apparently on a profit basis), no license is required if in lieu thereof the operator of the machines obtains an occupational license. Florida provides exemption from county and municipal license of operators of drinking cup and stamp machines when located in public conveyances. ${ }^{38}$ Machines vending drinking cups and those machines making non-profit sales to employees are also exempted under Mississippi statutes. ${ }^{30}$ In addition to stamp machines, North Carolina exempts peanut vending machines and machines vending candy containing $5^{\circ}$ percent peanuts. ${ }^{40}$ The state of South Dakota broadens its exemptions to include machines vending stamps, drinking cups, sanitary napkins, as well as utility meters. ${ }^{41}$ Texas appears to be the only state exempting service vending machines from license or tax. Cigarette vending machines are also exempt, because they are included in the definition of place of business in the cigarette tax. ${ }^{42}$ The states of Virginia and West Virginia limit their vending machine exemptions to one commodity. In the former only drinking cup machines, ${ }^{43}$ while in the latter only stamp machines ${ }^{44}$ are given favored treatment by the legislators. ${ }^{45}$

\section{FARMERs' CoOperatives}

Unique among unorthodox channels of distribution in having elicited legislative favoritism rather than hostility, cooperatives have already assumed an imposing position as a distributive agency. Over 15,000 farmer-controlled cooperatives are now in operation in this country. Of this number 10,752 are engaged in the marketing of farm products, the purchasing of farm supplies, or the rendering of related services. Data on reported membership and patronage indicate that more than 3,000,000 persons hold membership in these organizations and at least half a

in dollars of the amount deposited for machines requiring 30 cents or over; N. C. H. B. 6ro, increasing the state license tax on cigarette vending machines from $\$ 5$ to $\$ 10$, on I cent food or merchandise machines from 50 cents to $\$ 2$, and on 5 cent food or merchandise machines from $\$ 1$ to $\$ 4$. Inasmuch as the North Carolina proposal continues the grant to local subdivisions of a power to impose a tax not to exceed 50 percent of the state tax, the total potential and likely tax is exactly double the amount of the state exaction.

${ }^{37}$ Ala. Acts 1939, No. 398 , amending Ala. Gen. Acts 1935, No. r94, $\$ 348$, sch. 154 .

${ }^{38}$ FlA. Comp. Gen. Laws (Supp. 1940) §1279(19).

${ }^{8 B}$ Miss. Laws I940, c. I22.

${ }^{10}$ N. C. Code ANN. (Michie, I939) \$7880 (6r). “1 S. D. Code (1939) \$57.4101.

"Tex. Stat. (Vernon, 1926) art. 7047a-1, amended Tex. Laws 3d Sess. 1936, c. 495, art III, 614.

${ }^{3}$ VA. TAX CODE $\$ I 98$.

"W. Va. Laws 1939, c. II9 §ro, amending W. VA. Code ANs. (1937) §9r6.

${ }^{15}$ While most of the above exemptions have little or no significance from the point of view of governmental favoritism between competitive products, some, like North Carolina's exemption of peanut vending machines, do. Note on Governmental Product Favoritism, supra this issue, covers the whole range of this species of marketing barrier. See also text discussion at note 12, supra. 
million more patronize as non-members. Sales of farm products and farm supplies by American cooperatives exceed $\$ 2,000,000,000$ annually, with 295 associations reporting sales of more than $\$, 000,000$ each and 34 doing a business in excess of $\$ 10,000,000$ each. ${ }^{46}$

Marketing and purchasing cooperatives, locally owned, are to be found in every state in the union as well as in the District of Columbia, and Puerto Rico. Through the former, farmers are now marketing a wide variety of products ranging from beef steers to spinach. The purchasing cooperatives engage in the business of supplying farmers with feed, seeds, fertilizer, spray materials, farm machinery, petroleum products, and many other supplies. While most of these products would come under the classification of producers' goods, the farm cooperatives have more recently invaded the consumers' goods field. ${ }^{47}$

In general the marketing cooperative has not been regarded by private distributors as an important competitor. It was rather the purchasing cooperatives because of their closer similarity to retail and wholesale stores, as far as function is concerned, that were considered by retailers as an important competitor in the distributive field. Recently, however, marketing cooperatives also have been so regarded since they have added more and more purchasing services to their activities.

The farmers cooperative movement in the United States has a history of over I30 years. The first period began about I8ro when various cheese-making factories were cooperatively organized at Goshen, Connecticut. About the same time a similar establishment was attempted at South Trenton, New York. In I857 cooperative grain and livestock associations were formed in several states. A cooperative hog auction was organized in Illinois in 1860 , and the first known association for the marketing of fruit was formed in Hammonton, New Jersey, in $1867 .^{48}$

The second period in the history of the cooperatives coincided with the rise of the Grange. As previously mentioned the Grange sponsored cooperatives which would market farm products, buy supplies, and manufacture farm implements. In the opinion of some writers on cooperatives, "the great contribution of the National Grange, however, was the formulation and distribution by its executive committee, in 1875 , of a set of rules for the organization of cooperative stores." 49 'These efforts ended in failure in most instances. Only a few cooperatives organized at that time have survived and are functioning today.

The great impetus to the growth in the number and importance of the cooper-

"The Statistical Handbook of Farmers Cooperatives, Farm Credit Adm'n, Coop. Div. Bull. No. 26. (Nov. I938) I.

${ }^{47}$ According to the Ohio Farm Bureau News, "Farm Bureau Advisory Councils have been toying for many months with the realization that the average farm family spends more money for household and personal needs-consumers' goods." In response to this suggestion the Farm Bureau Cooperative Association of Columbus, Ohio, late in 1939 , started a mail-order service for household goods. To start with, only a few items are to be handled such as blankets, women's hose, men's shirts, and men's working clothing. Gradually other items will be added until the whole range of household supplies will be so distributed. (March I940) 50 MONTFil LABOR REv. 665.

${ }^{48}$ Elsworth, The Story of Farmers Cooperatives, Farm Credit Adm'n, Circ. E-23 (1940) I, 2.

10 Id. 2t 4. 
atives came after the World War. Beginning about 1920, and for several years thereafter, large-scale, centralized, cooperative marketing associations were formed for the "orderly marketing" of many agxicultural commodities. These centralized cooperatives differ from local associations primarily in that they operate over wider areas, and perform services more extensive in character than can be rendered by a local cooperative. In 1935 there were in operation more than roo large centralized cooperative associations, with a total membership of about 450,000 farmers. ${ }^{50}$

The present trend in the farmer cooperative movement indicates a shift from the simple, small, independent local enterprise to the large, complex organization. The newer associations go beyond the county shipping point to the large city market. Without doubt the most significant trend appears in the persistent growth in the importance of supply purchasing cooperatives. Whereas 25 years ago purchasing comprised less than 2 percent of the total cooperative business, now it is closer to 15 percent. ${ }^{51}$

What is believed to be the first law recognizing the cooperative method of buying and selling was passed by Michigan. In 1865 it put on its statute books "an act to authorize the formation of mechanics' and laboring men's cooperative associations." "52 It is Massachusetts, though, which is credited with being the first to enact a law, in 1866 , which gave full recognition to cooperative buying and selling by farmers. ${ }^{53}$ This law contained many of the provisions that are found in present cooperative marketing statutes. Other states soon followed the lead of Massachusetts. Most of the early laws provided only for stock corporations. California in I895 enacted the first law providing for cooperative non-stock associations.

It was not until the passage of the Clayton Act in $1914{ }^{54}$ supplementing the Sherman Anti-Trust Act, ${ }^{55}$ that Congress officially recognized the existence of nonstock, non-profit farmers' cooperatives. Several prior laws, including the Corporation Tax Law of $1909^{56}$ and the Tariff Act of $1913^{57}$ exempted from their taxing provisions "labor, agricultural, and horticultural organizations," but failed to mention whether or not these organizations were to be conducted for the mutual help of their members. The Clayton Act clarified the legal status of cooperatives for the first time when it excluded from its anti-trust and restraint of trade provisions "labor, agricultural, and horticultural organizations, instituted for the purpose of mutual help and not having capital stock or conducted for profit." The CapperVolstead Act of $1922^{58}$ gave legislative sanction for agricultural producers to organize cooperative associations provided that they were operated for the mutual benefit of the members.

The Cooperative Marketing Act of $1926^{59}$ was the first to acknowledge the advantages to the farmer in cooperative purchasing of farm supplies, and to offer

${ }^{50}$ Fetrow, Cooperative Marketing of Agricultural Products, Farm Credit Adm'n Bull. No. 3 (1936) 3.

${ }^{51}$ Elsworth, supra note 48 , at 26.

"s A Study of Farmers' Cooperatives in Virginia (Am. Retail Fed., 1940) (unpublished manuscript).

E\& 38 StaT. 730, 5 U. S. C. \$\$12-27; 38 STAT. 738, 29 U. S. C. $\$ 52$ (I914).

55 26 STAT. 209, I5 U. S. C. \$\$T-7 (1890).

c7 38 STAT. Ir4 (I9I3).

so 44 STAT. x895, 7 U. S. C. $\$ 45$ ( 1926$)$.

${ }_{58}{ }_{42}$ STAT. 388,7 U. S. C. $\$ \$ 291,292$ (1922). 
federal assistance to the cooperatives. The Secretary of Agriculture was directed to establish a Division of Cooperative Marketing ${ }^{60}$ which was (I) to make studies of the economic, legal, financial, social, and other phases of cooperation and to publish its findings; and (2) to promote the knowledge of cooperative principles and practices and to cooperate with educational and marketing agencies and cooperative associations in promoting this knowledge. Judging by the activities and publications of this division there is reason to believe that it does more than any other single government agency to promote and foster farmers' cooperatives.

Another federal act which rendered assistance to the cooperatives was the Agricultural Marketing Act of $1929 .{ }^{61}$ The Federal Farm Board was appointed by the President under this act and an appropriation of half a billion dollars was authorized for it as a revolving fund. ${ }^{62}$ Among other things this fund was designed to assist cooperatives by making loans available. Several new cooperatives were established soon after the Board was created which otherwise would probably not have been organized; in any event substantial aid in the form of loans from the revolving fund was extended to some of them.

The Farm Credit Act of $1933^{63}$ constituted further favorable legislation for cooperatives in that it authorized the establishment of twelve banks for cooperatives throughout the country, with a Central Bank for Cooperatives in the District of Columbia. Up to this time federal credit aid had been available only for marketing purposes, but under this act the central bank and the regional banks were authorized to make loans to all farmers' cooperatives, including both marketing and purchasing associations. The Farm Credit Act of $1935^{64}$ enlarged the lending powers of banks for cooperatives and amended the Agricultural Marketing Act to include associations furnishing farm business services, such as insurance, power, and transportation.

Although federal legislation plays an important rôle in promoting farmers' cooperatives, it should be noted that most of the laws governing the incorporation, regulation, and taxation of such cooperatives are state enactments. Furthermore, many state laws provide for a Division of Markets in the State Department of Agriculture, one of the duties of which is to assist in the organization of farmers' cooperative marketing and purchasing associations.

Promotive legislation on both the state and federal level has taken four distinct forms: ( $r$ ) financial aid at comparatively low interest rates; (2) exemption of the earnings of cooperatives from taxation; (3) special advantages in the laws of incorporation; and (4) educational, research, and promotional assistance. In the matter of tax exemptions it is interesting to note that although all types of dividends paid from whatever source by consumers' cooperatives are taxable, the Bureau of Internal Revenue has ruled "that a farm purchasing cooperative which buys groceries

${ }^{00}$ This is now part of the Farm Credit Administration. Under this law was created the present Cooperative Research and Service Division of the Farm Credit Administration.

${ }^{2} 46$ STAT. II, I2 U. S. C. \$\$II4I-Ir4Ij (I929).

02 The activities and funds of the Federal Farm Board were transferred to the Farm Credit Administration under Exec, Or. 6084, March 27, 1933.

${ }^{63} 48$ Star. 257 , 12 U. S. C. A. c. 7 (1933).

* 49 Stat. 313, I2 U. S. C. A. C. 7 (1935). 
or other consumers' goods for members is exempt from such taxation, provided that purchases for non-members do not exceed I5 percent of the total."05 Six states, however, exempt consumers' as well as farm cooperatives from taxation on amounts distributed as patronage dividends. ${ }^{66}$

In a number of states cooperatives are exempted from the "blue sky laws." Kansas, for example, expressly saves cooperatives from such regulation. ${ }^{07}$ The Federal Securities Act of 1933 also exempts "any security issued by a farmers' cooperative association." 68 In some states there are only limited or partial exemptions. Iowa, for example, exempts issues by cooperatives if the amount is for less than $\$ 25,000 .^{69}$ Blue sky exemption is no doubt based on the premise that these laws were designed primarily to protect investors, and that the purchase of stock in a cooperative is not truly an investment but rather a normal procedure in the establishment of a business relationship resulting in mutual service. ${ }^{70}$

Despite all the favorable promotive legislation and other forms of government protection, the cooperatives as innovations in the distributive field had to combat the antagonism of established and orthodox agencies. The means employed to curb their growth and influence were diverse, ranging from the spreading of false statements on methods of cooperative operation to boycotts through boards of trade or similar organizations. ${ }^{71}$

Now that farmers' cooperatives are an established phase of our distribution pattern, it is interesting to note the attitude of many of their leaders toward the consumers' cooperatives. "In recent legislative effort to establish credit 'parity' for consumer cooperatives, the voice of organized agriculture turned against it."72 It appears that owing to the antagonism of farm marketing cooperatives Congress refused in 1937 to grant funds to the Bureau of Agricultural Economics for a study of the possible effect of consumers' cooperative buying operations on farm income and prices. ${ }^{73}$

\section{Conctusions}

The conflicts and frictions between orthodox and newer, more direct, channels of distribution are continuous. Only the forms change; the basic rivalries remain the same. This is bound to be so in a free dynamic society where economic institutions are not ossified. Regardless of legislative restriction or favoritism, in a society where the ultimate consumers are the final arbiters, only those forms of distribution will survive and flourish which perform a function meeting the needs of the people. During the long evolutionary development of the present retailing system, there has gone on a relentless competition that in many instances ruthlessly discarded those forms of distribution found either uneconomical or otherwise without consumer favor. Discriminatory legislation has not stopped the peddler, itin-

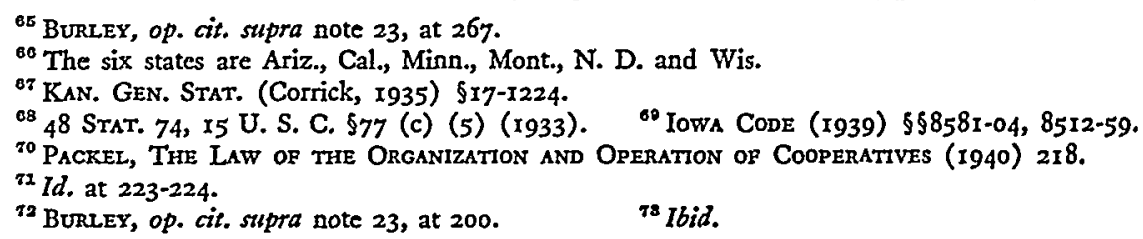


erant merchant, department store, mail-order house, or vending machine from finding a niche in our distributive system. Neither has promotive legislation given to the cooperatives a monopoly of the farmers' purchases. Unless our economic order should become a rigidly controlled politico-economic society, it is difficult to assume that present distribution methods will not be challenged by newer types not yet developed.

It is a pity, though, that vested institutions must invoke the aid of legislators in the forty-eight states and the Federal Government. The net result is usually discriminatory legislation not only between types of distributors within the state but also against agents from without the state. The consequence of it all is retaliatory laws causing further marketing barriers. Our present system of distribution is far from perfect. It is a developing process and hence affected by changes in our methods of production, our standards of living, and our concepts of ethics. No agency, therefore, can or should be regarded as the final one which must be preserved to the exclusion of novel methods called forth by new situations.

By and large, courts have been inclined to validate the legislation that has resulted from the appeal for governmental aid. Here, as with other legislative manipulation of the free market, judicial tolerance has been the rule. ${ }^{74}$ Recent months, however, have seen certain signs of judicial restiveness under the shackles imposed by the rule of abnegation, signs which perhaps foretell a trend toward court views of yesteryear. ${ }^{75}$ Two 1940 decisions seem to be of especial significance. Good Humor Corp. v. City of Long Beach ${ }^{76}$ invalidated an ordinance directed at ice cream peddlers because it was ". . in restraint of trade, unreasonable and discriminatory."77 There is in the making here a conception of a basic communion of spirit between due process and free competition, to the potentialities of which the pages of this journal only recently bore eloquent testimony. ${ }^{78} \mathrm{~A}$ second possible straw in the wind is N.J. Good Humor, Inc. v. Board of Comm'rs. ${ }^{79}$ Acting on the same philosophy, it invalidated a general prohibition on hawking as a "... subversion of competition ... not in the public interest, and the police power can only be addressed to that end." 80 Were such new coinage to come to enjoy common judicial currency, present intellectual fashions among the state judiciaries would fast lose circulation. Those fashions are not, however, without their devotees; typical is the action of an appellate Ohio court in sustaining a prohibition of ice cream peddlers in the name of little children. ${ }^{81}$ In the last analysis, therefore, the solution of the barrier problem must necessarily lie primarily with the people and their elected representatives.

\footnotetext{
74 An over-all evaluation of the part the judiciary has played in the barrier problem is to be found in Isaacs, Barrier Activities and the Courts: A Study in Anti-Competitive Law, infra this issue.

${ }^{75}$ See ibid. $\quad{ }^{76} 22$ N. Y. S. (2d) 382 (1940). ${ }^{77} I d$. at 383 (ital. added).

${ }^{78}$ Hamilton, Common Right, Due Process and Antitrust (1940) 7 LAw \& Contemp. Pros. 24.

${ }^{70}{ }_{124}$ N. J. L. 162 , II A. (2d) I13 (1940). ${ }^{80}$ II A. (2d) at II7.

${ }^{82}$ X-Cel Dairy v. City of Akron, 63 Ohio App. 147, 25 N. E. (2d) 700 (1939). Arnold v. Board of Examiners, 109 P. (2d) 779 (N. M. 194I), although a price-fixing case, is significant for its disposition of the contention that minimum-price fixation was violative of N. M. CoNsT. Art. IV, \$38: ". . the legislature shall enact laws to prevent trusts, monopolies and combinations in restraint of trade."
} 